\title{
Comparative Study of Different Configuration of Roof Truss for an Industrial Shed
}

\section{ABSTRACT}

High rise steel buildings account for a very small percentage of the total number of structures that are built around the world. The majority of steel structures being built are low rise buildings, which are generally of one storey only. Industrial buildings, a subset of low rise buildings are normally used for steel plants, automobiles industries, utility and process industries, thermal power stations, warehouses, assembly plants, storage, garages, small scale industries, etc. These buildings require large column free areas. Hence interior columns, walls, and partitions are often eliminated or kept minimum. Most of these buildings may require adequate head room for the use of an over travelling crane. In present study Different configuration of trusses and Pre Engineered buildings (PEB) structures were analyzed and designed as per relevant Indian codes using Staad pro software. The quantity of structural steel required for each quantity was compared to establish the economy of each structure.

Key words: High rise buildings, Pre Engineering Buildings (PEB), Roof Trusses.

\section{Corresponding Author: Yashwanth M K}

\section{INTRODUCTION}

Most building roofs can be framed with engineered light-gauge steel trusses which are manufactured from $\mathrm{C}$ shaped metal studs. Prefabricated steel trusses offer a high-strength, light-weight roof system that can be installed headed quickly. Roofs on more than $20 \%$ of all new commercial structures in the US are built with light gage steel roof systems are gaining ground in markets where additional strength is needed, or where greater free spans are required. A standard truss is a series of triangles- a stable geometric shape that is difficult to distort under load. Regardless of its overall size and shape, all the chords and webs of a truss form triangles. These triangles combine to distribute the load across each of the other members, resulting in a light structure that is stronger than the sum of the strength of its individual components.

\section{PRE ENGINEERED BUILDINGS (PEB)}

Technological improvement over the year has contributed immensely the enhancement of quality of life through various products and services. Once such revolution was the pre engineered buildings. 
Though its origin can be traced back to 1960's, its potential has been felt only during the recent years. This was mainly due to the development in technology, which helped in computerizing the design.

A recent survey by the metal building associations (MBMA) shows that about $60 \%$ of the non residential low rise buildings in USA are PEB's. Although PEB systems are extensively used in industrial and many other non residential constructions worldwide, it is relatively a new concept in India. The market potential of PEB's is 1.2 million tonnes per annum.

Pre engineered steel buildings can be fitted with different structural accessories including mezzanine floors, canopies, fascias, interior partitions etc. \& the building is made waterproof by use special mastic beads, filler strips and trims. This is very versatile building system and can be finished internally to serve any functions and accessorized externally to achieve attractive and unique designing styles. It is very advantageous over the conventional buildings and is really help full in the low rise building design.

PEB's are generally low rise buildings however the maximum height can go up to 25-30m. Low rise buildings are ideal for offices, houses, showrooms, shop fronts, etc. The application of PEB concept to low rise buildings is very economical and speedy. Buildings can be constructed in less than half the normal time especially when complemented with the other engineered sub systems.

The most common and economical type of low raise buildings, is a building with ground floor and two intermediate floor plus roof .The roof of low rise buildings may be flat or sloped. Intermediate floors of low rise building are made of mezzanine systems. Single storeyed houses for living take minimum time for construction and can be built in any type of geographical location like extreme cold hilly areas, high rain prone areas, plain land obviously and extreme hot climatic zones as well.

\section{OBJECTIVES}

- To adopt different configuration of trusses and PEB for an industrial shed under consideration.

- To analyze the truss with different configurations and PEB for gravity and wind load as per relevant Indian codes and to proportion the sizes of members to keep the internal forces and deformation within the limits.

- To compare the internal forces and deflection in different configuration of trusses and PEB for the loads under consideration.

- To compare the quantity of steel required for different configuration of trusses and PEB to compare the efficiency and economy of various configurations.

\section{METHODOLOGY}

- Industrial shed of medium span (about $12 \mathrm{~m}$ ) has been considered for present study.

- Different types of trusses such as Pratt, Howe, Parallel chord, Fan, Arch type and PEB Have been considered for present study.

- DL, LL and WL resulted on panel points have been calculated based on Indian code provisions. The required member sizes are found out.

- This truss have been analyzed and designed for calculated loads using Staad pro software.

- Internal forces such as axial force and deflection in each of the configuration have been compared. 
DOI : https://dx.doi.org/10.26808/rs.ed.i8v2.03

International Journal of Emerging Trends in Engineering and Development

Issue 8, Vol.2 (February- March 2018)

Available online on http://www.rspublication.com/ijeted/ijeted_index.htm

ISSN 2249-6149

- The quantity of steel required for each configuration is found out and compared to assess the economy of each configuration.

\section{PRESENT WORK}

The plan considered for the present study is as shown in the figure below

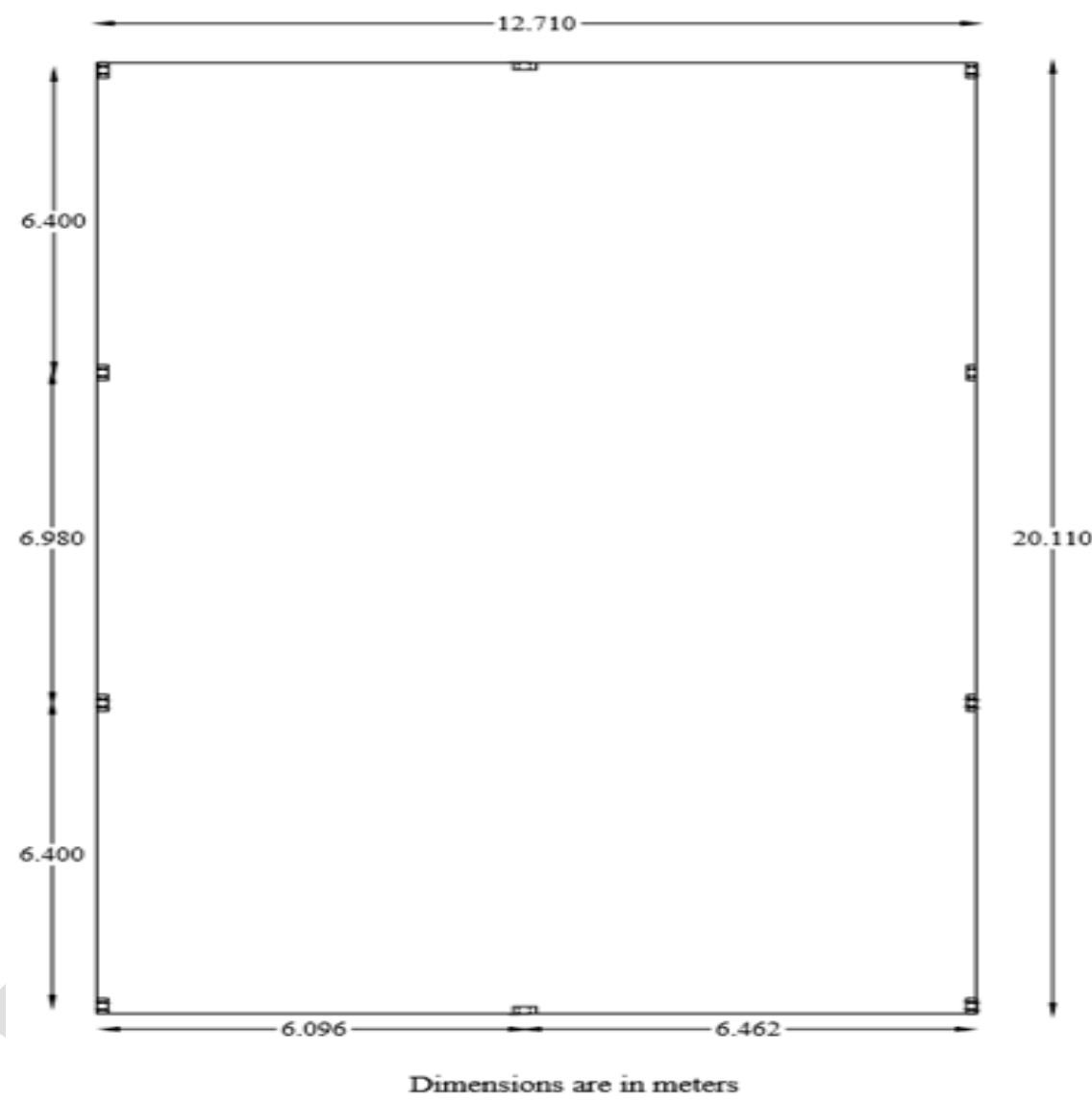

Fig 1: Plan Details of present Study

\section{Plan details}

- Location - Community hall near Mandya district, Karnataka, India.

- Area $-255.4 \mathrm{~m}^{2}$

- No. of trusses -2

- No. of columns - 10

- Roof sheet - Galvanized iron sheets

Purlins details

- Section - ISMC 200

- Length - $19.78 \mathrm{~m}$

- Spacing $-1.3 \mathrm{~m}$ 
DOI : $\underline{\text { https://dx.doi.org/10.26808/rs.ed.i8v2.03 }}$

International Journal of Emerging Trends in Engineering and Development

\section{SELECTION OF CONFIGURATION}

The calculation of various parameters involved with the configuration of the truss is as follows.

\begin{tabular}{|l|l|l|l|}
\hline Effective Span of Truss & $\mathrm{L}$ & 12.56 & $\mathrm{~m}$ \\
\hline Rise of truss & $\mathrm{H}=\mathrm{L} / 8$ & 1.65 & $\mathrm{~m}$ \\
\hline Length of Sloping Side & & 6.50 & $\mathrm{~m}$ \\
\hline Number of Panel Points & & 6 & no's \\
\hline Spacing of Purlins & $\begin{array}{l}\text { length of sloping side } \\
\text { (no. of p.points }-1)\end{array}$ & 1.33 & $\mathrm{~m}$ \\
\hline Spacing of truss & & 6.98 & $\mathrm{~m}$ \\
\hline Angle of inclination & $\tan ^{-1}\left(\mathrm{H} /\left(0.5^{*} \mathrm{~L}\right)\right)$ & 14.7 & Degrees \\
\hline Height to the Eve of Truss $=$ & & 4 & $\mathrm{~m}$ \\
\hline
\end{tabular}

Table1: Calculation of Various parameters

\section{LOAD CALCULATION}

Load Calculations for a typical truss is as shown below.

\begin{tabular}{|l|l|l|l|l|l|}
\hline Dead Load & & & & & \\
\hline Weight of Sheeting & & 0.131 & $\mathrm{kN} / \mathrm{sqm}$ & \multicolumn{2}{|l|}{ asperIS875 part1 } \\
\hline Weight of Fixtures and Others= & & 0.11 & $\mathrm{kN} / \mathrm{sqm}$ & & \\
\hline Total= & & 0.241 & $\mathrm{kN} / \mathrm{sqm}$ & & \\
\hline Weight of Purlin= & & 0.218 & $\mathrm{kN} / \mathrm{m}$ & & \\
\hline & & & & & \\
\hline Total dead Load on Panel Point= & & $\mathbf{3 . 7 2}$ & $\mathrm{KN}$ & & \\
\hline & & & & & \\
\hline Live Load & & & & & \\
\hline Live Load= & & 0.75 & $\mathrm{kN} / \mathrm{sq} \mathrm{m}$ & \multicolumn{2}{|l|}{ asper IS875 part2 } \\
\hline Reaction due to inclination= & & 0.66 & $\mathrm{kN} / \mathrm{sq} \mathrm{m}$ & asperIS875 part2 \\
\hline & & & & & \\
\hline Total live Load on Panel Point= & & $\mathbf{6 . 0 0}$ & $\mathrm{KN}$ & & \\
\hline & & & & & \\
\hline Wind Load & $\mathrm{V}$ & 33 & $\mathrm{~m} / \mathrm{s}$ & & \\
\hline Basic Wind Speed= & & & & \\
\hline
\end{tabular}


DOI : https://dx.doi.org/10.26808/rs.ed.i8v2.03

International Journal of Emerging Trends in Engineering and Development

Issue 8, Vol.2 (February- March 2018)

Available online on http://www.rspublication.com/ijeted/ijeted_index.htm

ISSN 2249-6149

\begin{tabular}{|l|l|l|l|l|l|}
\hline \hline $\mathrm{k} 1$ & & 1 & & \multicolumn{2}{|l|}{} \\
\hline $\mathrm{k} 2$ & & 1.03 & & & \\
\hline $\mathrm{k} 3$ & & 1 & & & \\
\hline Design Wind Speed & $\mathrm{V}_{\mathrm{z}}=\mathrm{V}_{\mathrm{b}} * \mathrm{k} 1 * \mathrm{k} 2 * \mathrm{k} 3$ & 33.99 & $\mathrm{~m} / \mathrm{s}$ & & \\
\hline Design Wind Pressure $=$ & $\mathrm{P}_{\mathrm{d}}=0.6 \mathrm{~V}_{\mathrm{z}}^{2}$ & 0.69 & $\mathrm{kN} / \mathrm{sqm}$ & & \\
\hline $\mathrm{h} / \mathrm{w}=$ & & 0.32 & & & \\
\hline External Pressure Coefficient= & $\mathrm{Cp}_{\mathrm{e}}$ & 0.9 & & & \\
\hline Internal Pressure Coefficient $=$ & $\mathrm{cp}_{\mathrm{i}}$ & 0.5 & & & \\
\hline area under consideration= $=$ & $\mathrm{A}$ & 9.2834 & & & \\
\hline wind Load on Panel Point $=$ & $\left(\mathrm{Cp} \mathrm{p}_{\mathrm{e}}-\mathrm{Cp} \mathrm{i}\right) \mathrm{Apd}$ & $\mathbf{8 . 8}$ & $\mathrm{kN}$ & & \\
\hline & & & & & \\
\hline Total load on each panel point $=$ & $\mathrm{DL}+\mathrm{LL}+\mathrm{WL}$ & $\mathbf{1 8 . 5 2}$ & $\mathrm{kN}$ & & \\
\hline
\end{tabular}

ANALYSIS AND OUTPUT

- Axial force diagram for Truss

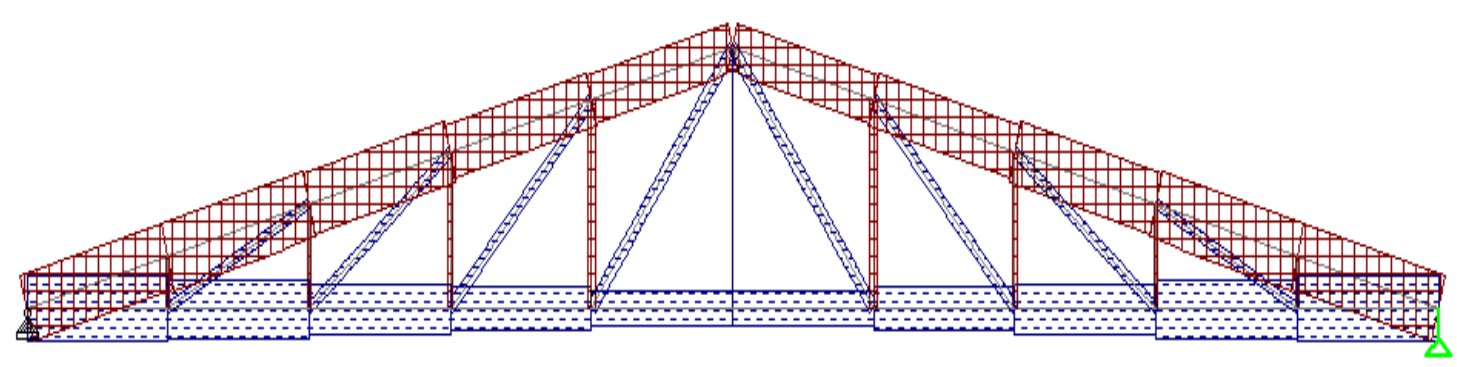

Fig 2: Axial force diagram for Pratt Type Truss

Fig 3: Axial force diagram for Howe Type Truss 
DOI : https://dx.doi.org/10.26808/rs.ed.i8v2.03

International Journal of Emerging Trends in Engineering and Development

Issue 8, Vol.2 (February- March 2018)

Available online on http://www.rspublication.com/ijeted/ijeted_index.htm

ISSN 2249-6149

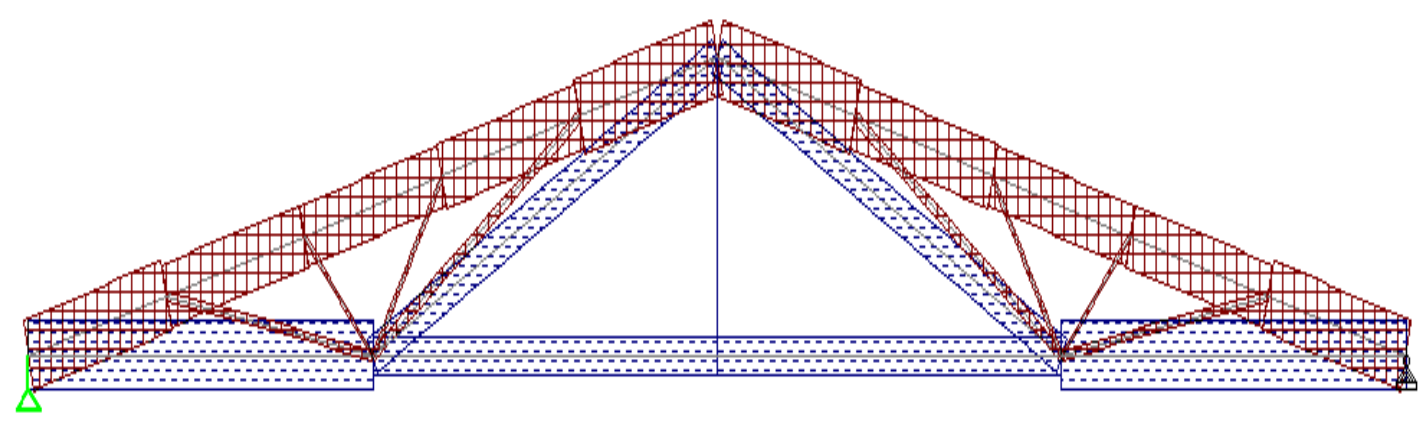

Fig 4: Axial force diagram for Fan Type Truss

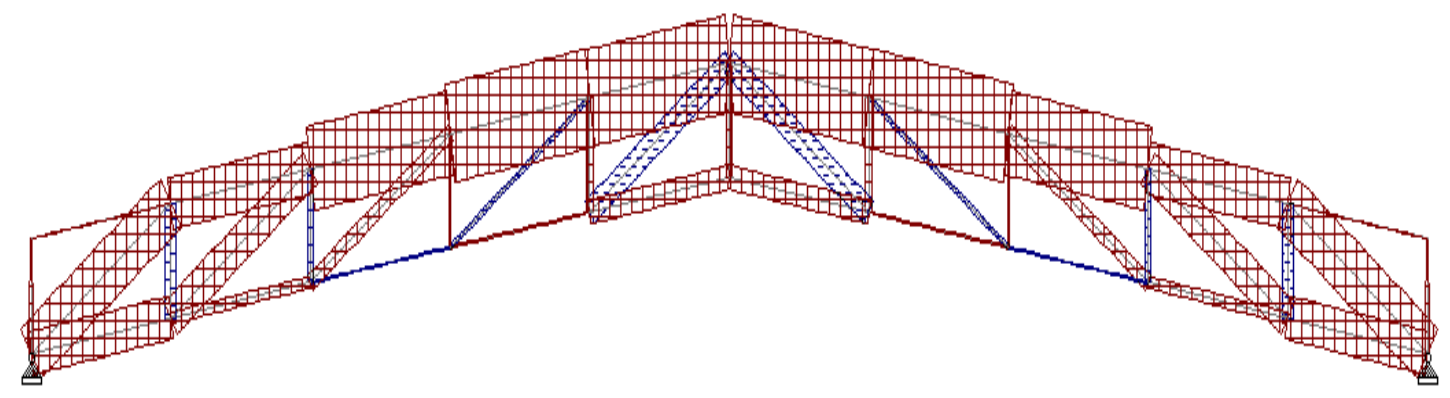

Fig 5: Axial force diagram for Parallel Chord Type Truss

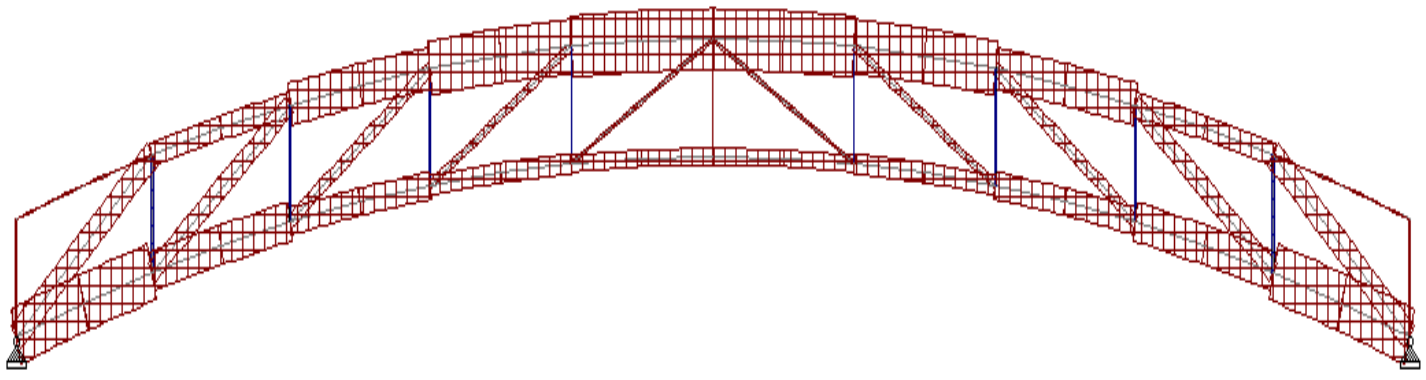

Fig 6: Axial force diagram for Arch Type Truss 


\section{BMD for PEB Structure}

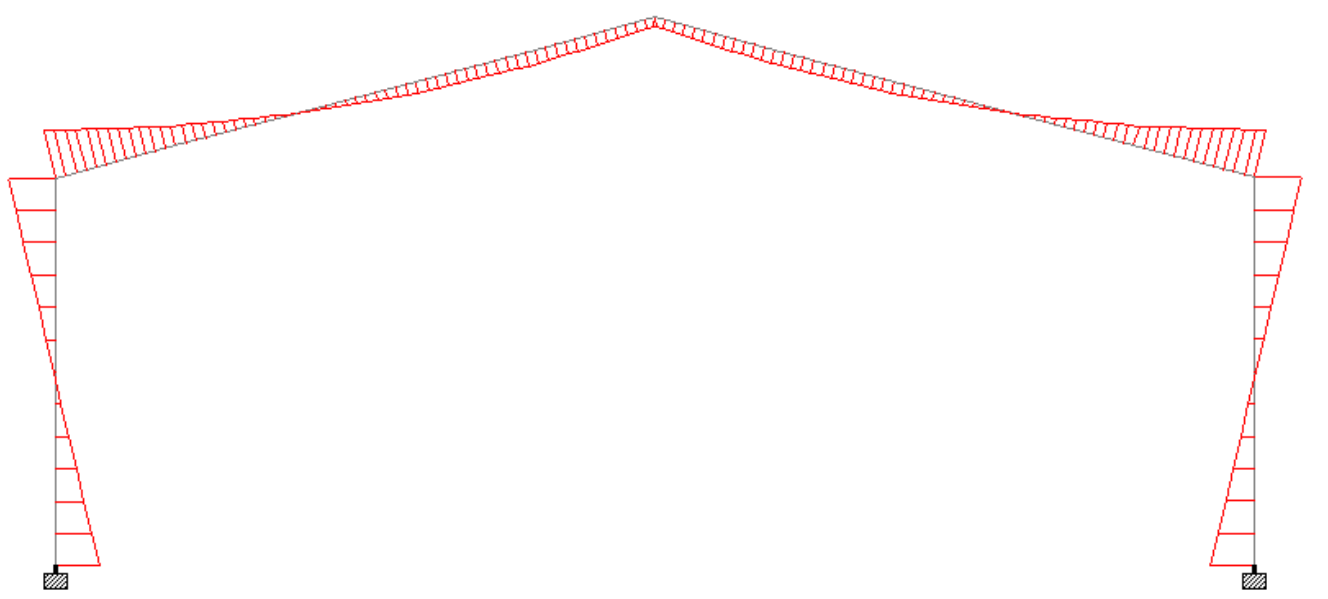

Fig 7: Bending Moment for PEB Structure

\section{RESULTS AND DISCUSSIONS}

The maximum internal forces, deflections and the quantity of steel required for different configurations of steel are as shown below in the Table

\begin{tabular}{|c|l|c|c|r|c|}
\hline Truss & Type & $\begin{array}{c}\text { Max Tension } \\
\text { in } \mathrm{kN}\end{array}$ & $\begin{array}{c}\text { Max comp } \\
\text { in } \mathrm{kN}\end{array}$ & $\begin{array}{l}\text { Deflection } \\
\text { in mm }\end{array}$ & $\begin{array}{l}\text { Steel Qty. } \\
\text { in tonnes }\end{array}$ \\
\hline 1 & Pratt & 377 & 399 & 37.66 & 0.5207 \\
2 & Howe & 161 & 393 & 41.75 & 0.5029 \\
3 & Fan & 380 & 419 & 43.14 & 0.695 \\
4 & Parallel chord & 106 & 251 & 13.79 & 0.3704 \\
\hline 5 & Arch & 78.1 & 182 & 14.26 & 0.268 \\
\hline 6 & PEB & & & 53.52 & 0.428 \\
\hline
\end{tabular}

Table 2: Maximum internals,dedlection and quantity of steel

The maximum tension, compressive forces, quantity of steel, deflection in the different configuration of trusses are compared in the following graph 
DOI : https://dx.doi.org/10.26808/rs.ed.i8v2.03

International Journal of Emerging Trends in Engineering and Development

Issue 8, Vol.2 (February- March 2018)

Available online on http://www.rspublication.com/ijeted/ijeted_index.htm

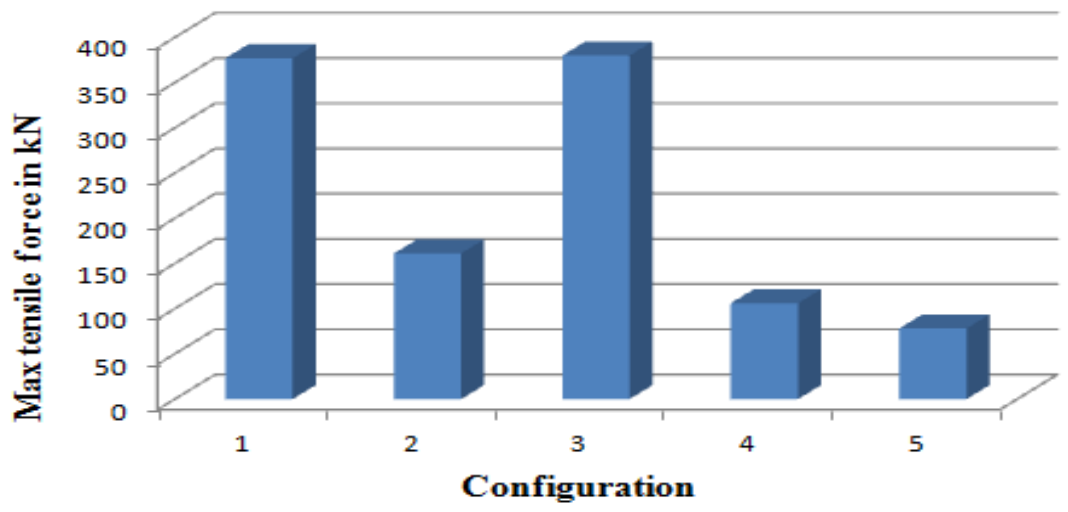

Fig 8: Maximum tensile force vs Configuration

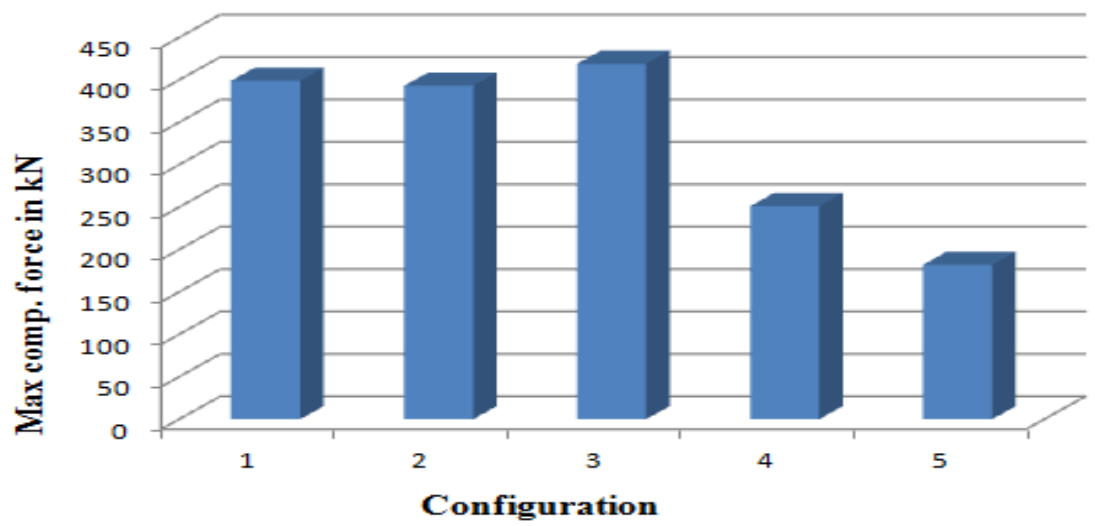

Fig 9: Maximum compressive force vs Configuration

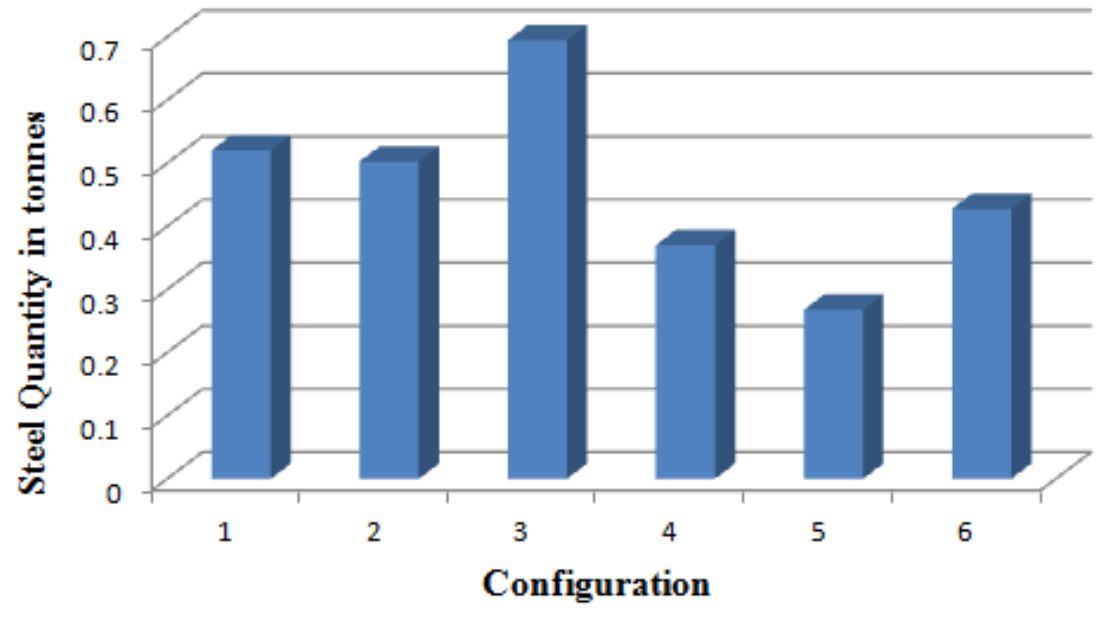

Fig 10: Steel quantity vs Configuration 


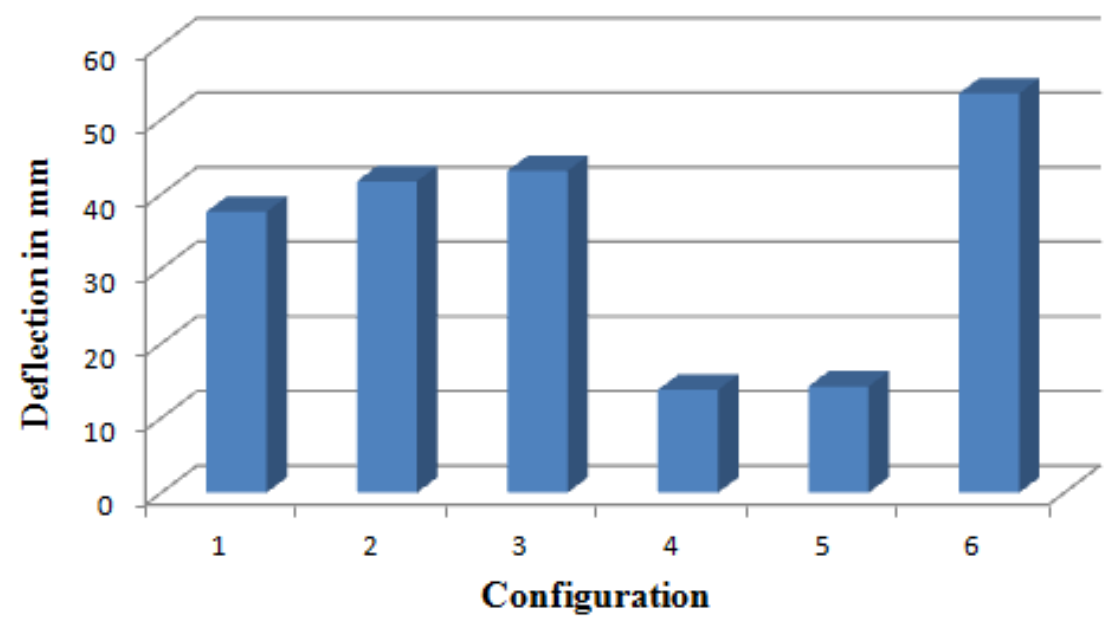

Fig 11: Deflection vs Configuration

From the above graph it can be seen that parallel chord and arch type truss undergo least deflection and requires least amount of quantity of steel.

\begin{tabular}{|c|c|c|c|c|c|}
\hline 1 & 2 & 3 & 4 & 5 & 6 \\
\hline Pratt & Howe & Fan & $\begin{array}{c}\text { Parallel } \\
\text { chord }\end{array}$ & Arch & PEB \\
\hline
\end{tabular}

Numbering Convention for Truss Configurations

\section{CONCLUSION}

Different configuration of trusses and PEB structures were analyzed and designed as per relevant Indian codes using Staad pro software. The quantity of structural steel required for each quantity was compared to establish the economy of each structure.

Following are the observations made:

- Among the conventional Pratt and Howe trusses, the major difference in the analytical behavior lies in the fact that the diagonal members are tension for gravity loads in Pratt configuration, while they are in compression in Howe configuration. The nature of forces are reversed in the case of uplift pressure.

- The comparison of total quantity of steel required for trusses reveals that the Arch type requires least amount of steel in comparison to the other configuration. Both Parallel chord and Arch type truss are very efficient in terms of economy.

- Comparison of total vertical deflection shows that Arch type of truss has the least deflection because of its advantageous shape.

- PEB are efficient in comparison to conventional Pratt, Howe and Fan trusses. Even though it proves slightly uneconomical in comparison to arch and parallel chord trusses. It has added advantages such as ease and speed of construction, better utilization of cross sections, aesthetics, etc. 


\section{REFERENCES}

I. B.C. Punmia, Ashok Kumar Jain and Arun Kumar Jain "Comprehensive Design of Steel structures", 10th Edition, Laxmi Publications, New Delhi, 2007.

II. Bhavikatti, "Design of Steel Structures", 6th Edition, University Press. Hyderabad, 2010

III. IS: 875 - 1987 (Part 2-Imposed Loads), "Code of Practice for Design Loads (other than earthquake) for Buildings and Structures", Bureau of Indian Standards, New Delhi.

IV. IS: 875 - 1987 (Part 1-Dead Loads), "Code of Practice for Design Loads (other than earthquake) for Buildings and Structures", Bureau of Indian Standards, New Delhi.

V. IS: 875 - 1987 (Part 3- Wind Loads), "Code of Practice for Design Loads (other than earthquake) for Buildings and Structures", Bureau of Indian Standards, New Delhi.

VI. IS:800-2007 "Indian Standard Code of Practice for General Construction in steel".

VII. S.K. Duggal, "Limit state design of steel structures", 1st Edition, TMH publication, 2011

VIII. Staad Pro V8i, Analysis Reference Manual.

IX. Subramanian N.,(2008), "Design of steel structures", Oxford university press, New Delhi, India. 